\title{
MENGEMBANGKAN KERJASAMA SISWA DENGAN MEDIA PEMBELAJARAN PAPEDA
}

\author{
Developing Student Cooperation Using Papeda
}

\author{
Nur Fitriyadi
}

\begin{abstract}
SD Negeri Kledokan, Tunjungan, Selomartani, Kalasan, Sleman, D.I. Yogyakarta, nurfitriyadi1988@gmail.com

ABSTRACT

Learning media are frequently used in teaching and learning activities. Papan Pinball Penyajian Data (Papeda) is a pinball board used for a game played with little rubber balls. The Papeda is played by some students in a group. This Classroom Action Research explored the use of Papeda to enhance the cooperation of fifth graders at Kledokan Elementary School in studying data presentation. The subjects of this study were 19 students. Data of students' cooperation was obtained using an observation sheet. Data analysis was carried out using qualitative data analysis techniques. The results of this study indicate that the use of Papeda was able to increase the cooperation of fifth graders at Kledokan Elementary School. The increase in students' cooperation can be seen in the aspects of: (1) helping each other in groups; (2) participating in creating a friendly atmosphere in the group; (3) acknowledging the advantages of other group members; (4) accepting the decisions made by the group; and (5) actively participating in working on group assignments.
\end{abstract}

Keywords: cooperation, Papeda, data presentation.

\begin{abstract}
ABSTRAK
Penelitian ini bertujuan meningkatkan kerjasama siswa kelas V SD Negeri Kledokan dalam pembelajaran. Penelitian ini merupakan Penelitian Tindakan Kelas (PTK) dengan melakukan pembelajaran pada mata pelajaran matematika materi penyajian data menggunakan media pembelajaran Papan Pinball Penyajian Data (Papeda). Subjek penelitian ini adalah siswa kelas V SD Negeri Kledokan berjumlah 19 anak. Data kerjasama siswa diperoleh menggunakan lembar observasi. Analisis data dilakukan dengan menggunakan teknik analisis data kualitatif. Hasil penelitian ini menunjukkan bahwa penggunaan media pembelajaran Papeda mampu meningkatkan kerjasama siswa kelas V SD Negeri Kledokan. Peningkatan Kerjasama tersebut terlihat pada aspek: (1) saling membantu teman dalam kelompok; (2) ikut menciptakan suasana akrab dalam kelompok; (3) mengakui kelebihan teman dalam kelompok; (4) menerima keputusan yang diambil kelompok; dan (5) berpartisipasi aktif dalam mengerjakan tugas kelompok.
\end{abstract}

Kata kunci: kerjasama, Papeda, penyajian data.

\section{PENDAHULUAN}

Dalam proses pembelajaran, kolaborasi merupakan bentuk kerjasama antarsiswa dengan saling membantu dan melengkapi dalam melakukan tugas-tugas tertentu untuk mencapai tujuan yang telah ditentukan. Kecakapan terkait kolaborasi dalam pembelajaran antara lain (1) menunjukkan kemampuan bekerjasama dalam kelompok secara efektif dan saling menghormati; (2) fleksibilitas secara pribadi, kemauan saling membantu, berkompromi untuk mencapai tujuan bersama; (3) bekerja secara produktif dengan yang lain, bertanggung jawab dan berkontribusi terhadap pekerjaan (Mahanal, 2014). Kerjasama merupakan karakter yang menunjukkan kebersamaan lebih unggul dibandingkan individu dalam mencapai tujuan kelompok (Widodo \& Lumintuarso, 2018). Belum berhasilnya pembelajaran yang dilakukan guru dapat disebabkan karena guru belum melaksanakan pembelajaran secara student center (Retnawati, 2011). Guru harus mampu menciptakan kegiatan pembelajaran yang mengembangkan sikap kerjasama. Kegiatan pembelajaran yang dimaksud adalah kegiatan yang mampu menghasilkan partisipasi semua siswa dan menempatkan siswa dalam tugas masing-masing. 
Kerjasama identik dengan kerja kelompok. Kenyataannya kedua hal tersebut tidaklah sama. Di kelas V SD Negeri Kledokan, Kecamatan Kalasan, Kabupaten Sleman, pada saat pembelajaran dilakukan secara kelompok, banyak siswa yang mengerjakan tugas dari guru tidak dengan bekerjasama. Biasanya, hanya beberapa anggota kelompok saja yang aktif mengerjakan tugas sementara anggota kelompok yang lain tidak berkontribusi. Tanpa kerjasama, kegiatan pembelajaran yang dilakukan secara berkelompok justru menimbulkan ketergantungan bagi siswa berkemampuan kognitif rendah dan sedang kepada siswa yang dianggap lebih pandai.

Dalam kelompok belajar yang dibentuk oleh guru, anggota kelompok masih lebih banyak bergantung kepada siswa yang dianggap pandai. Siswa yang memiliki kemampuan kognitif rendah kurang aktif memberi sumbangsih bagi kelompok. Mereka terlihat tidak antusias pada pembelajaran dan mudah menyerah saat mendapat tugas yang dianggap sulit. Siswa yang cerdas pun terkesan enggan membantu teman satu kelompok dan belum ada kesadaran untuk saling bekerjasama sebagai sebuah tim. Siswa yang kesulitan dalam belajar tidak mau bertanya atau meminta bantuan kepada teman yang telah memahami materi pelajaran.

Beberapa siswa masih menganggap pembelajaran adalah sebuah kompetisi. Persaingan ini menyebabkan siswa yang pandai enggan membantu siswa yang kurang pandai. Sebaliknya, siswa yang kurang pandai menjadi rendah diri untuk bertanya kepada teman sebaya. Adanya persaingan dalam hal hasil belajar menyebabkan hanya siswa-siswa cerdas saja yang mendominasi kelas. Setiap ada pertanyaan dari guru, beberapa siswa berebut menjawab. Namun, sebagian besar siswa lebih memilih diam. Mereka terkesan pasrah karena merasa tidak termasuk dalam pertarungan. Padahal, potensi yang mereka miliki sebenarnya tidak jauh berbeda dengan siswa-siswa yang cerdas karena latar belakang keluarga yang hampir sama. Dapat disimpulkan bahwa siswa belum terbiasa belajar secara kolaborasi.

Hasil observasi di SD Negeri Kledokan, Kecamatan Kalasan, Kabupaten Sleman menunjukkan hasil belajar siswa pada mata pelajaran Matematika cukup memuaskan. Hal ini dapat dilihat dari nilai Penilaian Tengah Semester (PTS) dan Penilaian Akhir Semester (PAS) semester ganjil tahun pelajaran 2018/2019. Rata-rata nilai PTS adalah 74 dan PAS 71. Meskipun rata-rata nilai siswa telah melampaui Kriteria Ketuntasan Minimal (KKM), selisih nilai tertinggi dan terendah terpaut sangat jauh. Ketimpangan terlihat dari beberapa siswa yang mendapat skor lebih dari 90 sedangkan beberapa siswa yang lain memperoleh skor di bawah 50. Hal ini selaras dengan temuan yang menunjukkan bahwa sinergitas belajar antar siswa belum berjalan optimal, sehingga berdampak terjadi ketimpangan belajar yang besar antar siswa.

Untuk mengoptimalkan pembelajaran, siswa kelas V di SD Negeri Kledokan perlu meningkatkan kerjasama mereka. Siswa yang termasuk dalam kelompok kognitif rendah perlu lebih aktif dalam pembelajaran. Mereka harus lebih berani untuk meminta bantuan teman-teman yang dirasa lebih menguasai materi pembelajaran. Siswa yang termasuk dalam kelompok kognitif tinggi juga harus bersedia menjadi mentor bagi teman yang belum menguasai materi pembelajaran dengan baik.

Pada Peraturan Menteri Pendidikan dan Kebudayaan Nomor 37 Tahun 2018 tentang KI dan KD, salah satu Kompetensi Dasar mata pelajaran Matematika kelas V berbunyi, "Menjelaskan penyajian data yang berkaitan dengan diri peserta didik dan membandingkan dengan data dari lingkungan sekitar dalam bentuk daftar, tabel, diagram gambar (piktogram), diagram batang, atau diagram garis". Kegiatan pembelajaran yang dilakukan antara lain membuat dan membaca tabel, diagram gambar (piktogram), diagram batang, dan diagram garis. Selama ini, tugas membuat tabel, diagram batang, diagram garis, atau diagram lingkaran diberikan oleh guru dari soal di buku paket atau dikembangkan sendiri guru. Siswa belum dilibatkan dalam penyusunan data untuk dijadikan soal padahal hal itu 
bisa dan penting dilakukan. Keterlibatan siswa dapat menumbuhkan keaktifan dan kerjasama dalam pembelajaran. Keberadaan media pembelajaran dapat membantu proses belajar ini.

Media pembelajaran adalah segala sesuatu yang dapat digunakan untuk menyampaikan pesan atau informasi dalam proses belajar mengajar sehingga dapat merangsang perhatian siswa dalam belajar (Azhar, 2014). Media pembelajaran merupakan suatu teknologi pembawa pesan atau sarana fisik yang dapat digunakan untuk menyampaikan materi pelajaran (Rusman, 2012). Media pembelajaran dapat membantu tugas guru untuk menyampaikan materi. Media pembelajaran juga berfungsi untuk menjembatani siswa dalam berinteraksi dengan sumber belajar dan memfokuskan perhatian siswa dalam pembelajaran. Penggunaan media pembelajaran dapat pula digunakan untuk meningkatkan kerjasama siswa (Rochaniningsih, 2015).

Salah satu media pembelajaran yang beprotensi dapat meningkatkan kerjasama adalah Papan Pinball Penyajian Data (Papeda). Papeda merupakan permainan menggunakan bola karet kecil sebagai alat bermain pada sebuah bidang pinball. Papan pinball yang digunakan sebagai media pembelajaran ini berupa papan berbahan kayu yang pada permukaan atasnya berjejer paku yang telah diatur jaraknya. Paku-paku ini berfungsi untuk menghambat bola karet meluncur secara lancar memasuki lubang paralon yang ditempatkan berjejer di bagian yang lebih rendah pada permukaan papan. Komponen Media Pembelajaran Papeda terdiri dari: (1) Papan Pinball, (2) Kertas Label Bergambar, (3) Bola Karet, (4) Lembar Kerja, seperti tersaji pada Gambar 1.

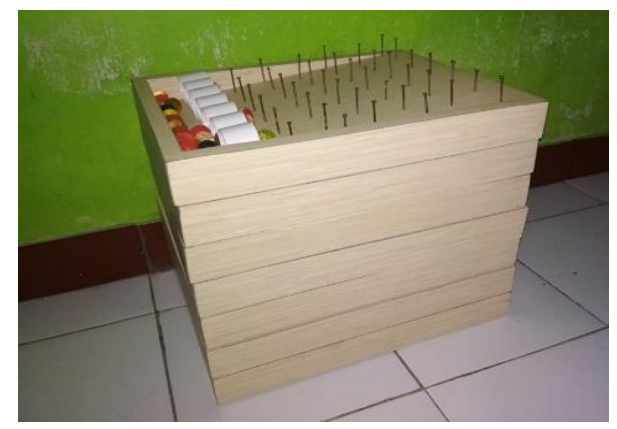

(1)

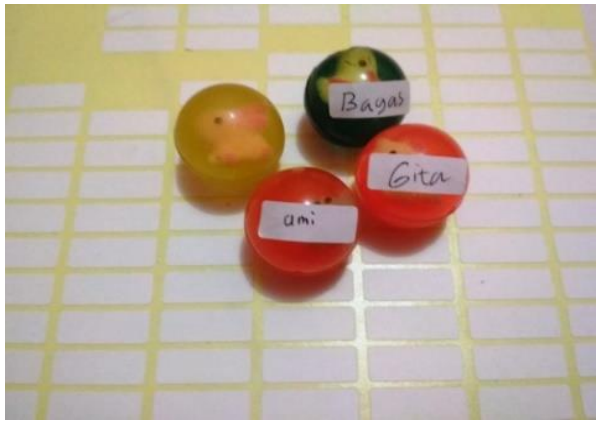

(3)

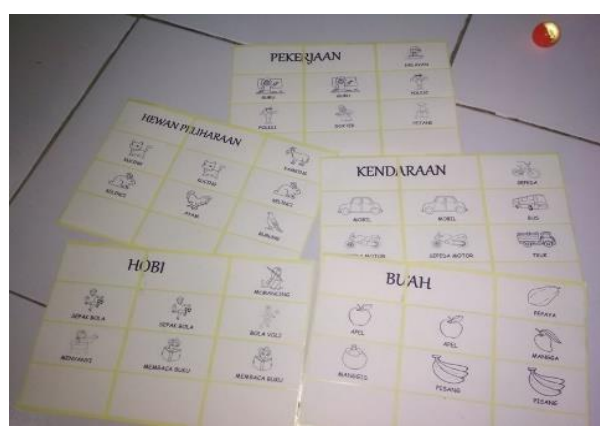

(2)

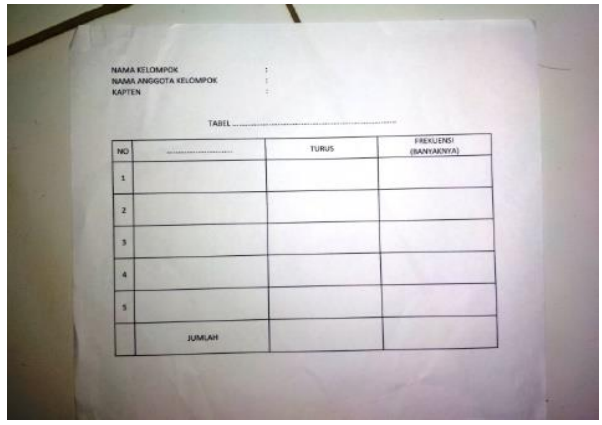

(4)

Gambar 1. Komponen Media Pembelajaran Papeda: (1) Papan Pinball, (2) Kertas Label Bergambar, (3) Bola Karet, (4) Lembar Kerja

Media pembelajaran Papeda digunakan secara berkelompok di mana setiap siswa mendapat satu bola karet untuk digelindingkan di atas permukaan papan pinball. Hasil lemparan bola yang masuk pada lubang paralon yang telah ditempeli gambar tertentu dicatat dalam tabel. Hal ini mengharuskan siswa membuat pembagian tugas yang jelas dalam kelompok. Dengan setiap siswa memiliki satu bola, akan menimbulkan rasa saling membutuhkan sehingga terjadi interaksi antar anggota kelompok. Adanya interaksi akan berdampak baik bagi tumbuhnya sikap kerjasama siswa. Sehingga, 
hipotesis pada penelitian ini adalah Papeda dapat meningkatkan kerjasama siswa kelas V SD Negeri Kledokan.

\section{METODE}

Penelitian ini merupakan Penelitian Tindakan Kelas (PTK) yang dilaksanakan pada bulan Februari dan Maret 2019 di SD Negeri Kledokan, Kecamatan Kalasan, Kabupaten Sleman, DIY. Penelitian ini dilakukan pada semester genap tahun pelajaran 2018/2019. Kelas yang menjadi objek penelitian adalah kelas V dengan jumlah siswa 19 anak. Intervensi pembelajaran dalam penelitian ini dilakukan secara siklik menggunakan model Kemmis \& McTaggart, meliputi: perencanaan, pelaksanaan dan observasi, serta refleksi. Menurut Kemmis \& McTaggart (1991), acting (pelaksanaan) dan observing (pengamatan) dijadikan sebagai satu kesatuan disebabkan antara penerapan acting dan observing harus dilakukan dalam satu waktu saat tindakan berlangsung.

Sesuai dengan model PTK menurut Kemmis \& McTaggart, pelaksanaan penelitian ini dilakukan secara siklik, meliputi: perencanaan, pelaksanaan dan observasi, dan refleksi. Tahap perencanaan dilakukan dengan merancang berbagai penunjang yang digunakan untuk penelitian. Perancangan ini dituangkan pada Rencana Pelaksanaan Pembelajaran (RPP). Penggunaan RPP akan membantu pendidik untuk melaksanakan suatu proses pembelajaran. Pada tahap pelaksanaan, dilakukan perbaikan pembelajaran melalui pemanfaatan media pembelajaran Papeda. Usaha yang dilakukan bertujuan untuk memperbaiki pembelajaran. Teman sejawat dilibatkan dalam pelaksanaan tindakan ini. Observasi untuk mengamati kerjasama siswa dilakukan pada masing-masing siklus. Lembar observasi diisi oleh observer sesuai dengan pengamatan saat pembelajaran berlangsung. Pelaksanaan refleksi bertujuan menganalisis hasil observasi yang sudah dilaksanakan untuk mengetahui kelemahan-kelemahan yang perlu diperbaiki. Kelemahan ini nantinya akan dikaji sebagai landasan untuk perbaikan pada siklus berikutnya. Jika belum ada kesesuaian seperti yang diharapkan, akan digunakan beberapa variasi pada kegiatan pembelajaran selanjutnya sebagai upaya penyempurnaan.

Pengumpulan data penelitian ini dilakukan untuk mengetahui peningkatan kerjasama siswa. Data kerjasama diperoleh dari lembar observasi dengan skala 4. Skor 4 diberikan jika kerjasama siswa sangat terlihat. Skor 3 diberikan jika kerjasama siswa cukup terlihat. Skor 2 diberikan jika kerjasama siswa kurang terlihat. Sementara, skor 1 diberikan jika kerjasama siswa tidak terlihat. Indikator pencapaian karakter kerjasama pada lembar observasi mengacu pada Sukardi \& Sugiyanti (2013) antara lain (1) saling membantu teman dalam kelompok; (2) ikut menciptakan suasana akrab dalam kelompok; (3) mengakui kelebihan teman dalam kelompok; (4) menerima keputusan yang diambil kelompok; dan (5) berpartisipasi aktif dalam mengerjakan tugas kelompok. Lembar observasi kerjasama siswa tersaji pada Tabel 1 berikut.

Tabel 1. Lembar Observasi Kerjasama Siswa

\begin{tabular}{|c|c|c|c|c|c|c|c|}
\hline \multirow[b]{2}{*}{ No } & \multirow[b]{2}{*}{ Nama } & \multicolumn{6}{|c|}{ Indikator } \\
\hline & & $\begin{array}{c}\text { Saling } \\
\text { Membantu } \\
\text { Teman } \\
\text { dalam } \\
\text { Kelompok } \\
\end{array}$ & $\begin{array}{c}\text { Ikut } \\
\text { Menciptakan } \\
\text { Suasana } \\
\text { Akrab dalam } \\
\text { Kelompok } \\
\end{array}$ & $\begin{array}{c}\text { Mengakui } \\
\text { Kelebihan } \\
\text { Teman } \\
\text { dalam } \\
\text { Kelompok } \\
\end{array}$ & $\begin{array}{c}\text { Menerima } \\
\text { Keputusan } \\
\text { yang Diambil } \\
\text { Kelompok }\end{array}$ & $\begin{array}{c}\text { Berpartisipasi } \\
\text { Aktif dalam } \\
\text { Mengerjakan } \\
\text { Tugas } \\
\text { Kelompok } \\
\end{array}$ & Jumlah \\
\hline 1 & Siswa 1 & & & & & & \\
\hline 2 & Siswa 2 & & & & & & \\
\hline 3 & Siswa 3 & & & & & & \\
\hline 4 & Dst. & & & & & & \\
\hline \multicolumn{8}{|c|}{ Rata-rata } \\
\hline \multicolumn{8}{|c|}{ Persentase } \\
\hline
\end{tabular}


Analisis data dilakukan dengan menggunakan teknik analisis data kualitatif. Data kualitatif dari hasil observasi dianalisis dengan menggunakan pendekatan deskriptif kuanitatif melalui persentase dengan rumus sebagai berikut.

$$
\text { Persentase indikator kerja sama }=\frac{\text { rata-rata indikator }}{\text { nilai maksimal rata-rata isian per indikator }} \times 100 \%
$$

Intervensi pembelajaran dalam penelitian ini dilakukan secara siklik, di mana putaran tindakan berlangsung secara terus menerus hingga penelitian menemukan titik puncak keberhasilan yang diharapkan. Kriteria keberhasilan penelitian ini adalah meningkatkannya kerjasama siswa kelas $\mathrm{V}$ SD Negeri Kledokan dalam pembelajaran mencapai $75 \%$ atau lebih. Apabila persentase indikator kerjasama belum mencapai 75\% penelitian akan dilanjutkan ke siklus berikutnya, dan jika persentase indikator kerjasama telah mencapai $75 \%$ atau lebih, penelitian dianggap berhasil.

\section{HASIL DAN PEMBAHASAN}

\subsection{Hasil Penelitian Siklus I}

Siklus I terdiri atas dua pertemuan dengan rincian materi: (1) jenis-jenis data dan penyajiannya; (2) praktik pengumpulan data. Kegiatan yang dilakukan pada tahap ini adalah mempelajari jenis-jenis data dan cara penyampaiannya serta mengumpulkan data jumlah kendaraan yang melintas. Materi tentang jenis-jenis data dipelajari di dalam kelas, sedangkan pembelajaran praktik mengumpulkan data kendaraan yang melintas dilaksanakan di pinggir jalan dekat sekolah. Sebelum praktik mengumpulkan data, siswa dibentuk menjadi beberapa kelompok dengan anggota heterogen. Pada saat kegiatan ini, observer mengamati dan mencatat hal-hal yang berkaitan dengan kerjasama siswa. Gambar 2 merupakan dokumentasi kegiatan pada Siklus I.

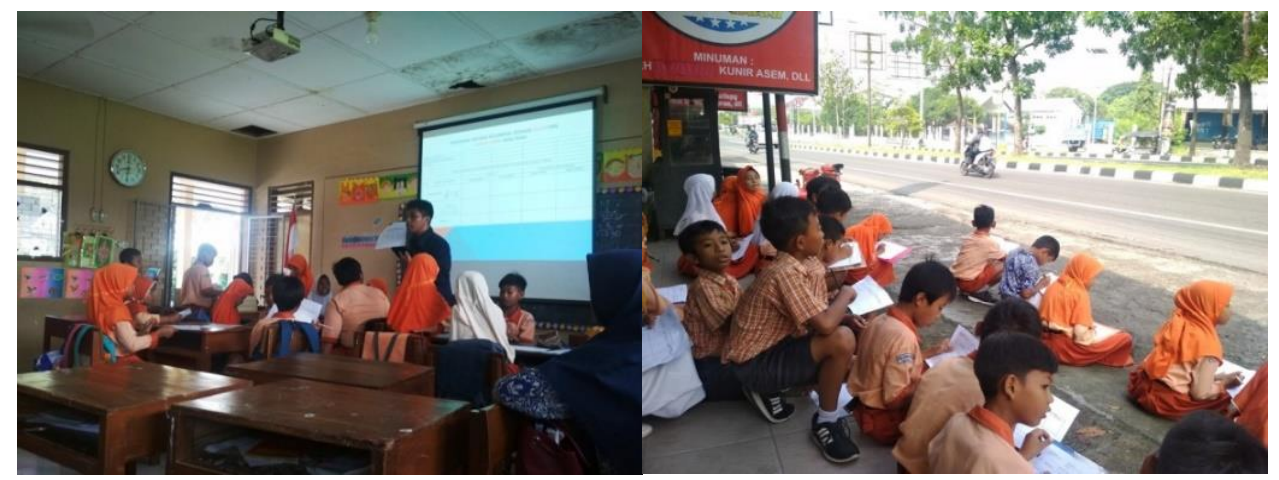

(1)

(2)

Gambar 2. Kegiatan Pembelajaran Pada Siklus I

Gambar 2(1) menunjukkan kegiatan pembelajaran di kelas dimana siswa mempelajari materi tentang jenis-jenis data. Siswa terlihat fokus memperhatikan guru yang sedang memberikan penjelasan di depan kelas. Pemahaman siswa tentang materi tentang jenis-jenis data ini selanjutnya digunakan sebagai dasar bagi mereka melakukan praktik mengumpulkan data kendaraan yang melintas dilaksanakan di pinggir jalan dekat sekolah. Gambar 2(2) menunjukkan kegiatan siswa pada saat praktik mengumpulkan data kendaraan yang melintas dilaksanakan di pinggir jalan dekat sekolah. Hasil pencatatan data dituangkan dalam lembar kerja yang telah disiapkan guru, seperti terlihat pada Gambar 3. 


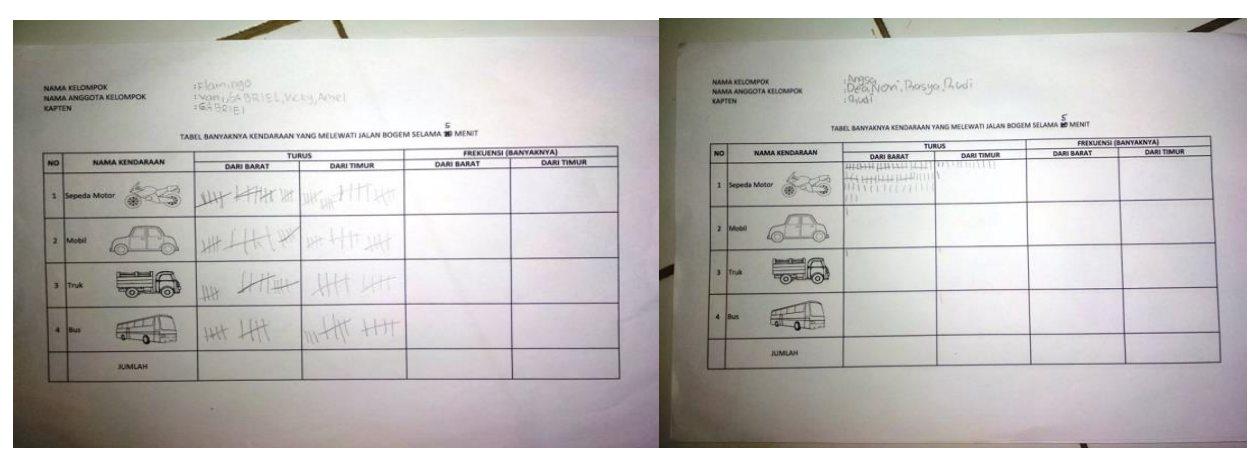

Gambar 3. Hasil Pengumpulan Data Kendaraan yang Melintas

Gambar 3 menunjukkan hasil kerja siswa yang menunjukkan belum adanya kerjasama di antara mereka. Berdasarkan pengisian data yang terlihat pada Gambar 3 ditemukan bahwa data hasil pencatatan siswa masih kurang memuaskan sebab terdapat kelompok yang melakukan pencatatan asal-asalan dan tidak sesuai kenyataan. Misalnya, siswa mencatat jumlah bus dan truk hampir sama dengan jumlah mobil, padahal kenyataannya jumlah mobil jauh lebih banyak. Ada pula kelompok yang hanya mencatat jumlah sepeda motor saja. Hal ini disebabkan pembagian tugas terhadap masing-masing anggota kelompok tidak dilakukan dengan baik yang mengindikasikan kurangnya kerjasama antarsiswa. Karena ketidakberhasilan dalam pembuatan data tersebut, pembelajaran membuat diagram belum dapat dilakukan.

Pada saat siswa melakukan praktik mengumpulkan data kendaraan yang melintas dilaksanakan di pinggir jalan dekat sekolah dilakukan pengamatan oleh observer. Pengamatan ini dilakukan untuk mengumpulkan data kerjasama pada peserta didik. Ada 5 (lima) aspek kerjasama yang menjadi focus pengamatan, yaitu: 1) saling membantu teman dalam kelompok; (2) ikut menciptakan suasana akrab dalam kelompok; (3) mengakui kelebihan teman dalam kelompok; (4) menerima keputusan yang diambil kelompok; dan (5) berpartisipasi aktif dalam mengerjakan tugas kelompok. Hasil pengamatan terhadap kelima aspek kerjasama tersebut didata melalui lembar pengamatan yang telah disiapkan. Hasil observasi kerjasama siswa hasil pengamatan yang dilakukan pada Siklus I disajikan pada Tabel 2.

Tabel 2. Hasil Observasi Kerjasama Siswa pada Siklus I

\begin{tabular}{|c|c|c|c|c|c|c|c|}
\hline \multirow[b]{2}{*}{ No } & \multirow[b]{2}{*}{ Nama } & \multicolumn{6}{|c|}{ Indikator } \\
\hline & & $\begin{array}{c}\text { Saling } \\
\text { Membantu } \\
\text { Teman } \\
\text { dalam } \\
\text { Kelompok } \\
\end{array}$ & $\begin{array}{c}\text { Ikut } \\
\text { Menciptakan } \\
\text { Suasana } \\
\text { Akrab dalam } \\
\text { Kelompok } \\
\end{array}$ & $\begin{array}{c}\text { Mengakui } \\
\text { Kelebihan } \\
\text { Teman } \\
\text { dalam } \\
\text { Kelompok }\end{array}$ & $\begin{array}{c}\text { Menerima } \\
\text { Keputusan } \\
\text { yang Diambil } \\
\text { Kelompok }\end{array}$ & $\begin{array}{c}\text { Berpartisipasi } \\
\text { Aktif dalam } \\
\text { Mengerjakan } \\
\text { Tugas } \\
\text { Kelompok } \\
\end{array}$ & Jumlah \\
\hline 1 & ANL & 3 & 3 & 3 & 3 & 4 & 16 \\
\hline 2 & AS & 2 & 2 & 3 & 3 & 2 & 12 \\
\hline 3 & BJA & 3 & 4 & 3 & 3 & 3 & 16 \\
\hline 4 & CVP & 2 & 3 & 3 & 3 & 4 & 15 \\
\hline 5 & DNW & 1 & 2 & 2 & 2 & 1 & 8 \\
\hline 6 & DEW & 2 & 3 & 3 & 3 & 2 & 13 \\
\hline 7 & DNH & 1 & 3 & 2 & 3 & 1 & 10 \\
\hline 8 & FW & 1 & 3 & 2 & 2 & 1 & 9 \\
\hline 9 & HSDN & 3 & 3 & 3 & 3 & 3 & 15 \\
\hline
\end{tabular}




\begin{tabular}{|c|c|c|c|c|c|c|c|}
\hline \multirow[b]{2}{*}{ No } & \multirow[b]{2}{*}{ Nama } & \multicolumn{6}{|c|}{ Indikator } \\
\hline & & $\begin{array}{c}\text { Saling } \\
\text { Membantu } \\
\text { Teman } \\
\text { dalam } \\
\text { Kelompok } \\
\end{array}$ & $\begin{array}{c}\text { Ikut } \\
\text { Menciptakan } \\
\text { Suasana } \\
\text { Akrab dalam } \\
\text { Kelompok } \\
\end{array}$ & $\begin{array}{c}\text { Mengakui } \\
\text { Kelebihan } \\
\text { Teman } \\
\text { dalam } \\
\text { Kelompok } \\
\end{array}$ & $\begin{array}{c}\text { Menerima } \\
\text { Keputusan } \\
\text { yang Diambil } \\
\text { Kelompok }\end{array}$ & $\begin{array}{c}\text { Berpartisipasi } \\
\text { Aktif dalam } \\
\text { Mengerjakan } \\
\text { Tugas } \\
\text { Kelompok }\end{array}$ & Jumlah \\
\hline 10 & HAA & 2 & 3 & 3 & 3 & 2 & 13 \\
\hline 11 & $\mathrm{MNH}$ & 1 & 2 & 2 & 3 & 1 & 9 \\
\hline 12 & MAFO & 4 & 4 & 3 & 3 & 3 & 17 \\
\hline 13 & MRE & 3 & 4 & 3 & 2 & 3 & 15 \\
\hline 14 & NAF & 4 & 2 & 3 & 3 & 3 & 15 \\
\hline 15 & REF & 1 & 2 & 2 & 1 & 1 & 7 \\
\hline 16 & RAR & 4 & 3 & 4 & 3 & 4 & 18 \\
\hline 17 & RA & 2 & 3 & 3 & 3 & 3 & 14 \\
\hline 18 & RAD & 2 & 3 & 2 & 2 & 3 & 12 \\
\hline 19 & ZA & 1 & 2 & 3 & 2 & 1 & 9 \\
\hline \multicolumn{2}{|c|}{ Rata-rata } & 2,21 & 2,84 & 2,74 & 2,63 & 2,37 & 12,78 \\
\hline \multicolumn{2}{|c|}{ Persentase } & 55 & 71 & 68 & 66 & 59 & 63,95 \\
\hline
\end{tabular}

Dari hasil observasi yang tersaji pada Tabel 2, diketahui bahwa kegiatan pembelajaran pada Siklus I menunjukkan kurangnya kerjasama siswa. Hal ini dapat dilihat terutama dalam hal saling membantu teman dalam kelompok dan partisipasi aktif dalam mengerjakan tugas kelompok. Banyak siswa yang bekerja secara individu. Belum ada satu pun indikator kerjasama yang mencapai $75 \%$. Persentase indikator tertinggi adalah "ikut menciptakan suasana yang akrab dalam kelompok" dengan $71 \%$. Kondisi ini terjadi seperti pada pembelajaran-pembelajaran berkelompok sebelumnya yang menunjukkan siswa masih kurang dalam hal membantu teman kelompok. Selain itu, masih banyak siswa yang tidak berpartisipasi aktif dalam kelompok. Rata-rata persentase indikator kerjasama keseluruhan baru mencapai $63,95 \%$.

Berdasarkan temuan selama pelaksanaan siklus 1 selanjutnya dilakukan refleksi oleh peneliti. Refleksi dilakukan untuk mengidentifikasi keterlaksanaan dan keberhasilan Tindakan yang telah diberikan dalam meningkatkan kerjasama siswa. Dengan mempertimbangkan hasil observasi pada Tabel 2 peneliti menganggap bahwa tindakan yang telah dilakukan belum memberikan hasil seperti yang telah ditetapkan pada kriteria keberhasilan. Hal ini mendorong peneliti untuk melakukan tindaan lanjutan pada siklus berikutnya. Peneliti menyimpulkan bahwa diperlukan upaya lanjutan untuk dapat meningkatkan kerjasama siswa dengan memanfaatkan media pembelajaran Papeda. Peneliti kemudian melanjutkan penelitian pada siklus II.

\subsection{Hasil Penelitian Siklus II}

Siklus II terdiri atas dua pertemuan dengan rincian materi: (1) praktik pengumpulan data dan (2) penyajian data dalam bentuk diagram. Kegiatan yang dilakukan pada tahap ini adalah praktik mengumpulkan data menggunakan media pembelajaran Papeda dan menyajikannya dalam bentuk diagram. Sama seperti pada siklus I, siswa dibentuk menjadi beberapa kelompok dengan anggota yang heterogen. Pada saat kegiatan pembelajaran, observer bertugas mengamati dan mencatat halhal yang berkaitan dengan kerjasama siswa.

Pembelajaran pada siklus II dimulai dengan membagikan papan Papeda, bola karet, kertas label, dan lembar kerja kepada setiap kelompok. Selanjutnya, siswa menempel kertas label pada potongan pipa paralon dan melakukan uji coba menggunakan bola karet. Hasil lemparan bola karet dicatat dalam 
lembar kerja. Pada saat kegiatan ini, siswa perlu berhati-hati karena adanya paku-paku yang terdapat pada papan Papeda. Gambar 4, 5, dan 6 berikut merupakan dokumentasi kegiatan pada Siklus II.

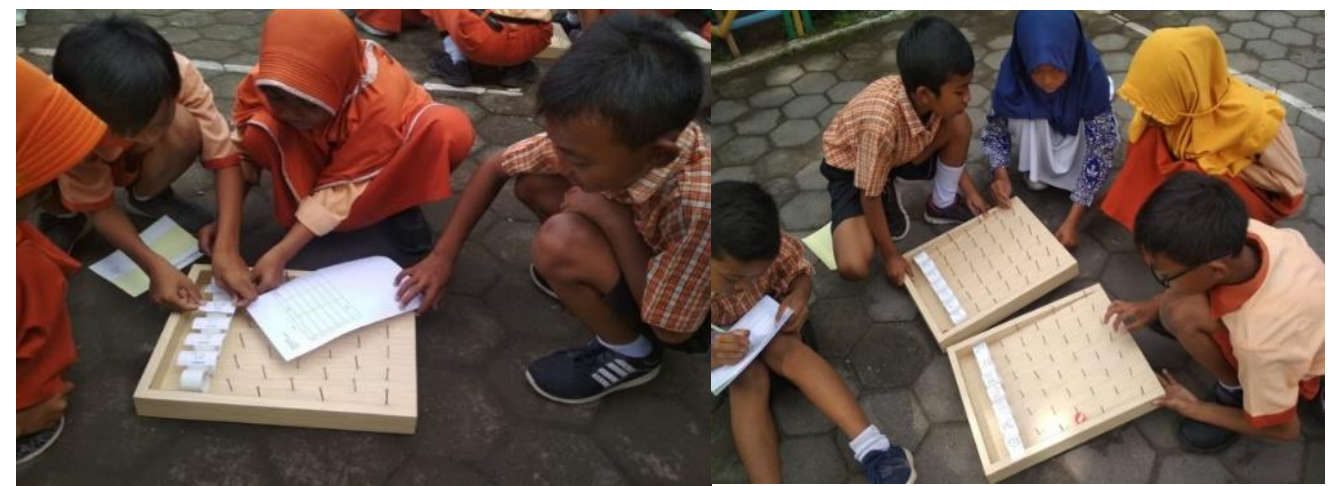

Gambar 4. Siswa Menempel Kertas Label pada Potongan Pipa Paralon dan Melakukan Uji Coba

Gambar 4 menunjukkan kegiatan siswa sedang menempel kertas label pada potongan pipa pralon dan melakukan ujicoba. Pada Gambar 4 terlihat bahwa setiap siswa terlibat secara aktif sesuai dengan tanggungjawab masing-masing.

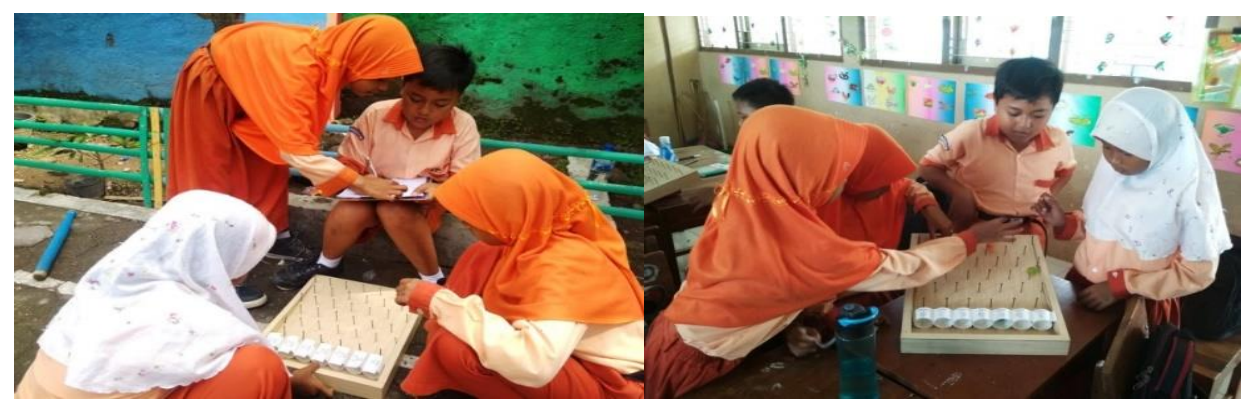

Gambar 5. Siswa Mencatat Hasil Lemparan Bola

Gambar 5 mrenunjukkan kegiatan siswa mencatat hasil lemparan bola. Seperti halnya pada tahap menempel kertas label pada potongan pipa pralon dan melakukan ujicoba, seperti telihat pada Gambar 4, pada kegiatan mencatat hasil lemparan bola ini juga terlihat jelas kerjasama seluruh anggota kelompok. Pembelajaran dengan media Papeda telah mengiteraksikan setiap siswa dengan kelompoknya melalui tugas-tugas yang telah dibagi diantara mereka.Saat pembelajaran menggunakan Papeda ini siswa bekerja sesuai dengan pembagian tugas yang telah disepakati oleh anggota kelompok. Pembagian tugas tersebut antara lain menempel kertas label pada paralon, mengisi identitas pada lembar kerja, dan mencatat hasil lemparan bola karet pada lembar kerja.

Pencatatan dilakukan melalui lembar pencatatan yang telah disiapkan. Setiap kelompok menuliskan temuan datanya sesuai dengan format yang telah disiapkan. Hasil pencatatan yang dilakukan salah satu kelompok disajikan pada Gambar 6. 


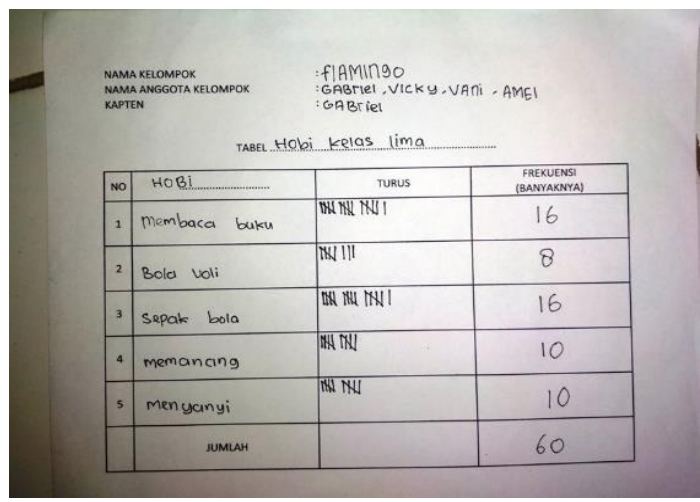

Gambar 6. Hasil Pencatatan Data Menggunakan Media Pembelajaran Papeda

Gambar 6 menunjukkan hasil pencatatan data menggunakan Papeda yang lebih rapi daripada saat pembelajaran Siklus I. Setelah semua kelompok selesai mencatat hasil lemparan bola karet, lembar kerja yang telah terisi tersebut digunakan sebagai acuan dalam membuat diagram. Siswa berkolaborasi membuat diagram batang pada bukunya masing-masing. Gambar 7 dan 8 berikut merupakan dokumentasi kegiatan tersebut.

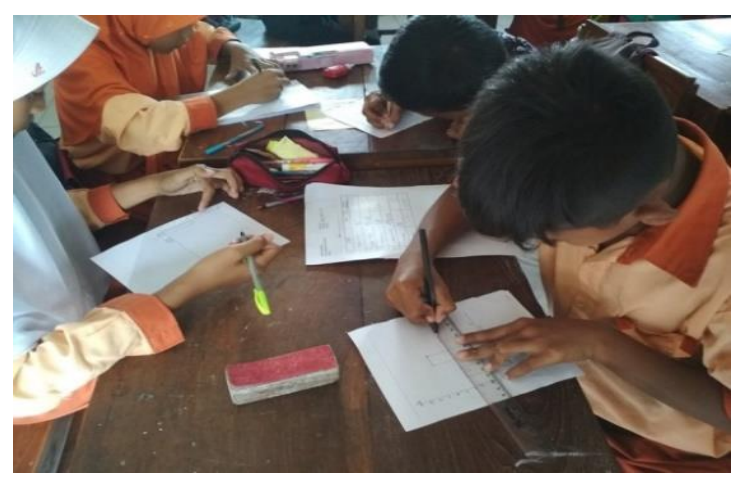

Gambar 7. Siswa Bekerjasama Menyajikan Data dalam Bentuk Diagram

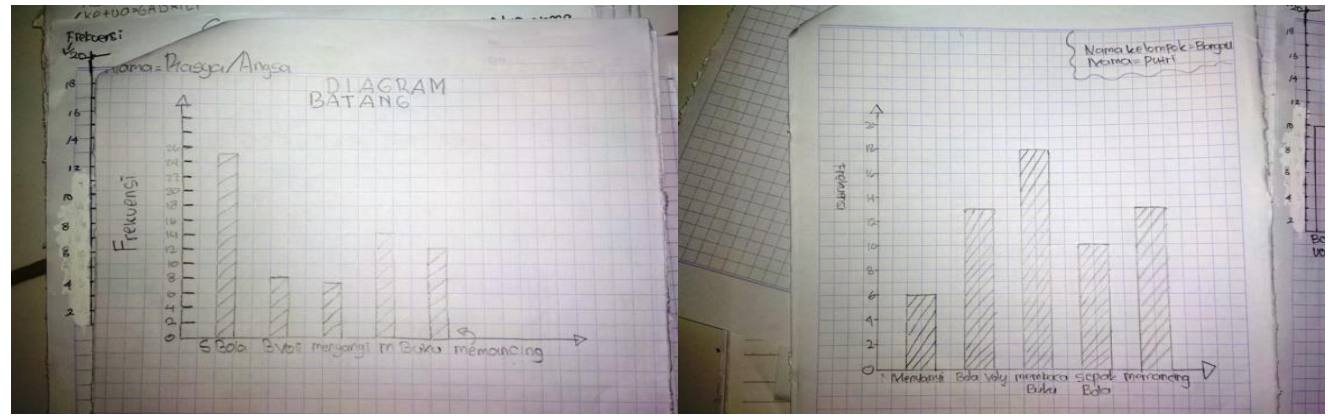

Gambar 8. Contoh Diagram yang Dibuat Siswa

Data hasil lemparan bola karet yang tersaji dalam tabel kemudian disajikan kembali dalam bentuk diagram batang. Saat proses ini, siswa saling bekerjasama dalam kelompok untuk menyajikan diagram batang yang baik. Hal ini dapat dilihat pada Gambar 7, di mana siswa terlihat aktif dalam pembelajaran. Hasil pembuatan diagram batang pun cukup memuaskan seperti terlihat pada Gambar 8.

Pada kegiatan pembelajaran Siklus II, siswa bisa lebih bekerjasama dalam kelompok. Masing-masing siswa saling membantu teman dalam kelompoknya. Hal yang paling terlihat jelas adalah hampir seluruh siswa berpartisipasi aktif dalam pembelajaran. Tidak ditemukan siswa yang bekerja secara individual. Seluruh anggota kelompok mengerjakan tugas sesuai dengan pembagian tugas yang sudah disepakati. Hasil observasi kerjasama siswa pada Siklus II disajikan pada Tabel 3. 
Tabel 3. Hasil Observasi Kerjasama Siswa pada Siklus II

\begin{tabular}{|c|c|c|c|c|c|c|c|}
\hline \multirow[b]{2}{*}{ No } & \multirow[b]{2}{*}{ Nama } & \multicolumn{6}{|c|}{ Indikator } \\
\hline & & $\begin{array}{l}\text { Saling Membantu } \\
\text { Teman dalam } \\
\text { Kelompok } \\
\end{array}$ & $\begin{array}{l}\text { Ikut Menciptakan } \\
\text { Suasana Akrab } \\
\text { dalam Kelompok }\end{array}$ & $\begin{array}{c}\text { Mengakui } \\
\text { Kelebihan Teman } \\
\text { dalam Kelompok }\end{array}$ & $\begin{array}{c}\text { Menerima } \\
\text { Keputusan yang } \\
\text { Diambil Kelompok }\end{array}$ & $\begin{array}{c}\text { Berpartisipasi Aktif } \\
\text { dalam Mengerjakan } \\
\text { Tugas Kelompok }\end{array}$ & Jumlah \\
\hline 1 & ANL & 4 & 4 & 4 & 4 & 4 & 20 \\
\hline 2 & AS & 3 & 4 & 4 & 4 & 4 & 19 \\
\hline 3 & BJA & 4 & 4 & 4 & 4 & 4 & 20 \\
\hline 4 & CVP & 4 & 4 & 4 & 4 & 4 & 20 \\
\hline 5 & DNW & 2 & 2 & 2 & 3 & 4 & 13 \\
\hline 6 & DEW & 3 & 4 & 3 & 4 & 4 & 18 \\
\hline 7 & $\mathrm{DNH}$ & 2 & 3 & 3 & 4 & 4 & 16 \\
\hline 8 & FW & 2 & 3 & 3 & 4 & 4 & 16 \\
\hline 9 & $\begin{array}{c}\text { HSD } \\
\mathrm{N}\end{array}$ & 4 & 4 & 4 & 4 & 4 & 20 \\
\hline 10 & HAA & 4 & 4 & 4 & 4 & 4 & 20 \\
\hline 11 & $\mathrm{MNH}$ & 2 & 2 & 3 & 4 & 3 & 14 \\
\hline 12 & $\begin{array}{c}\text { MAF } \\
\mathrm{O}\end{array}$ & 4 & 4 & 4 & 4 & 4 & 20 \\
\hline 13 & MRE & 4 & 4 & 4 & 4 & 4 & 20 \\
\hline 14 & NAF & 4 & 3 & 4 & 4 & 4 & 19 \\
\hline 15 & REF & 1 & 3 & 3 & 3 & 4 & 14 \\
\hline 16 & RAR & 4 & 4 & 4 & 4 & 4 & 20 \\
\hline 17 & RA & 4 & 4 & 4 & 4 & 4 & 20 \\
\hline 18 & RAD & 4 & 3 & 4 & 4 & 4 & 19 \\
\hline 19 & $\mathrm{ZA}$ & 4 & 3 & 3 & 3 & 4 & 17 \\
\hline & a-rata & 3,32 & 3,47 & 3,58 & 3,84 & 3,95 & 18,15 \\
\hline Per & entase & 83 & 87 & 89 & 96 & 99 & 90,79 \\
\hline
\end{tabular}

Tabel 3 menunjukkan bahwa berdasarkan hasil observasi terhadap 5 (lima) indikator kerjasama ditemukan bahwa kelima indikator tersebut telah melampaui target yang diharapkan yaitu $75 \%$. Secara berturut-turut, persentase yang diperoleh $83 \%, 87 \%, 89 \%, 96 \%$, dan $99 \%$ dengan rata-rata 90,79\%. Dalam hal ini, karena target $75 \%$ telah terpenuhi, penelitian dinyatakan berhasil.

\subsection{Pembahasan}

Pendidikan karakter di sekolah dilaksanakan dengan mengintegrasikannya pada proses pembelajaran (Sukardi dan Sugiyanti, 2013). Pembelajaran yang dimaksud dapat berupa penerapan model, metode, maupun media pembelajaran yang tepat. Menurut Lickona (1991), pengembangan karakter, salah satunya kerjasama, dapat terjadi melalui peningkatan pengetahuan (knowing the good), sikap (desiring the good), dan perilaku positif (doing the good). Menurut Schaefer (2012), pendidikan karakter kerjasama yang efektif antara lain dilakukan melalui pendekatan student centered. Pembelajaran yang dilakukan hendaknya dapat mengaktifkan peserta didik (Endarwati, 2020).

Kerjasama siswa dapat meningkat dengan belajar penyajian data menggunakan media pembelajaran Papeda. Peningkatan tersebut dapat dilihat dari hasil observasi yang menunjukkan bahwa semua indikator kerjasama siswa mengalami kenaikan rata-rata yang cukup signifikan. Dengan media pembelajaran Papeda, siswa dituntut untuk aktif dalam belajarnya dan saling membantu anggota kelompok. Adanya interaksi yang terjadi di dalam kelompok saat pembelajaran menggunakan media 
pembelajaran Papeda menyebabkan siswa wajib bekerjasama. Tabel 4 merupakan perbandingan persentase indikator kerjasama pada Siklus I dan Siklus II.

Tabel 4. Perbandingan Persentase Indikator Kerjasama

\begin{tabular}{ccc}
\hline Indikator & $\begin{array}{c}\text { Siklus I } \\
(\%)\end{array}$ & $\begin{array}{c}\text { Siklus II } \\
(\%)\end{array}$ \\
\hline Saling Membantu Teman dalam Kelompok & 55 & 83 \\
\hline Ikut Menciptakan Suasana Akrab dalam Kelompok & 71 & 87 \\
\hline Mengakui Kelebihan Teman dalam Kelompok & 68 & 89 \\
\hline Menerima Keputusan yang Diambil Kelompok & 66 & 96 \\
\hline Berpartisipasi Aktif dalam Mengerjakan Tugas Kelompok & 59 & 99 \\
\hline
\end{tabular}

Tabel 4 menunjukkan bahwa telah terjadi peningkatan pada kelima aspek kerjasama. Hasil observasi terhadap 5 (lima) indikator kerjasama pada siklus I dan II tersebut menunjukkan kelima indikator tersebut mengalami peningkatan. Indikator "saling membantu teman dalam kelompok" mengalami peningkatan dari $55 \%$ menjadi $83 \%$ atau meningkat $28 \%$. Indikator "ikut menciptakan suasana yang akrab dalam kelompok" mengalami peningkatan dari $71 \%$ menjadi $87 \%$ atau meningkat $16 \%$. Indikator "mengakui kelebihan teman dalam kelompok" mengalami peningkatan dari $68 \%$ menjadi $89 \%$ atau meningkat $21 \%$. Indikator "menerima keputusan yang diambil oleh kelompok" mengalami peningkatan dari $66 \%$ menjadi $96 \%$ atau meningkat 30\%. Indikator "berpartisipasi aktif dalam mengerjakan tugas kelompok" mengalami peningkatan tertinggi dari 59\% menjadi $99 \%$ atau meningkat $40 \%$. Dengan demikian, ditemukan bahwa peningkatan paling tinggi terjadi pada indikator berpartisipasi aktif dalam mengerjakan tugas kelompok, meningkat sebesar $40 \%$. Peningkatan paling sedikit terjadi pada indikator ikut menciptakan suasana akrab dalam kelompok, meningkat sebesar $16 \%$. Walaupun peningkatannya paling kecil, tetapi pada indikator tersebut persentase kerjasamanya telah mencapai $87 \%$, di atas batas yang telah ditetapkan sebesar $75 \%$.

Secara grafis, perbandingan persentase indikator kerjasama disajikan pada Gambar 9.

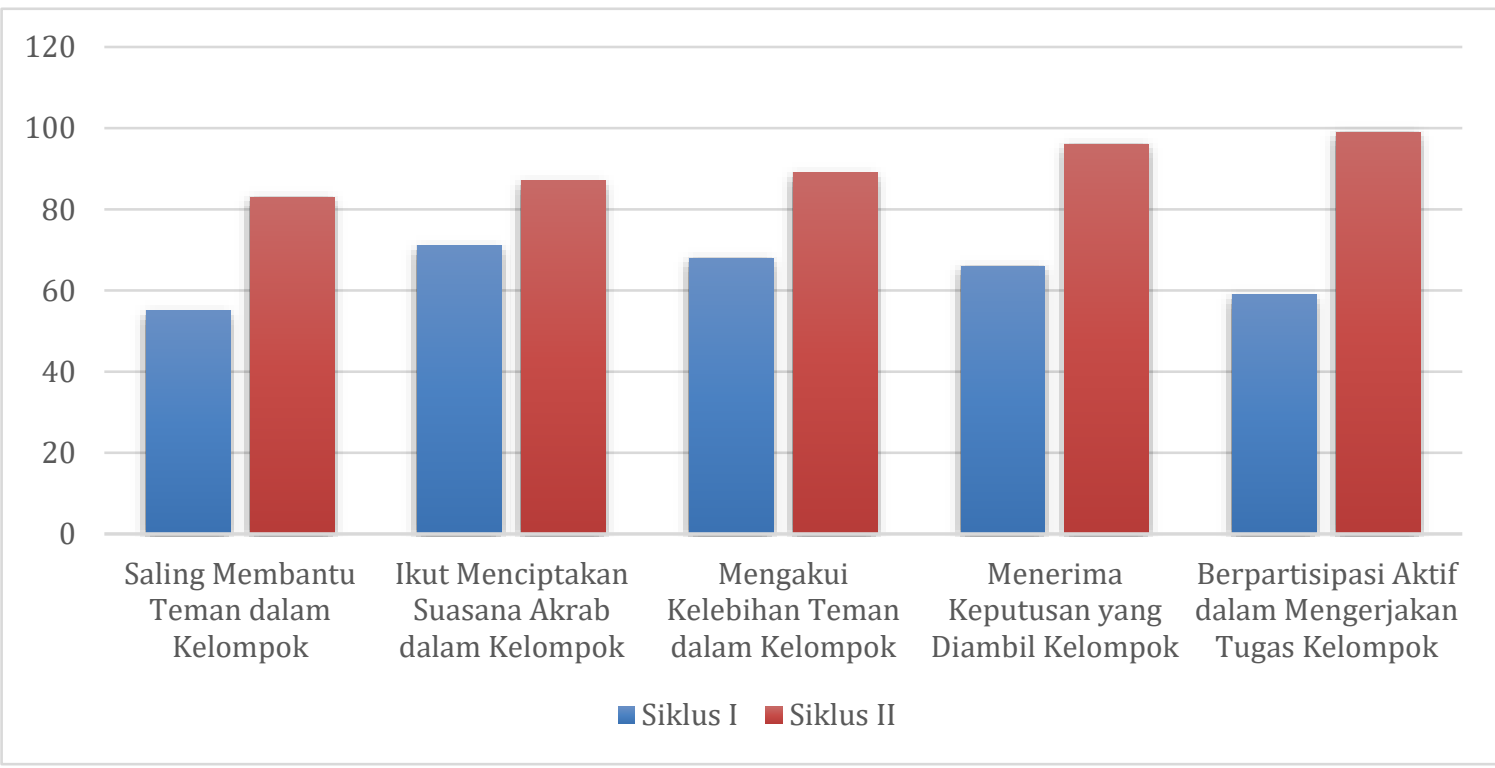

Gambar 9. Grafik Perbandingan Persentase Indikator Kerjasama Siklus I dan Siklus II (dalam \%) 
Gambar 9 menunjukkan dengan lebih jelas bahwa telah terjadi peningkatan seluruh indikator kerjasama. Hal ini menunjukkan bahwa penggunaan Papeda sebagai media pembelajaran berupa permainan memberikan andil terhadap meningkatnya indikator-indikator kerjasama. Pada dasarnya, anak sekolah dasar kelas $\mathrm{V}$ masih senang bermain sehingga guru seharusnya merancang pembelajaran yang memungkinkan adanya unsur permainan di dalamnya (Mardati dan Wangid, 2015). Pemilihan permainan yang tepat dalam pembelajaran akan menentukan karakter pada anakanak (Nur, 2013). Papeda merupakan media pembelajaran yang seru jika dioperasikan bersama-sama dalam kelompok. Dengan Papeda, siswa dituntut belajar penyajian data dengan bekerjasama dalam tim. Gambar 9 menunjukkan grafik perbandingan persentase indikator kerjasama pada Siklus I dan Siklus II.Seluruh indikator kerjasama meningkat setelah digunakannya media pembelajaran Papeda. Peningkatan indikator-indikator kerjasama siswa pun sangat signifikan. Hal ini membuktikan bahwa media pembelajaran Papeda efektif untuk meningkatkan kerjasama siswa.

\section{SIMPULAN DAN SARAN}

\subsection{Simpulan}

Berdasarkan hasil penelitian ini dapat disimpulkan bahwa penggunaan media pembelajaran Papeda mampu meningkatkan kerjasama siswa kelas V SD Negeri Kledokan. Peningkatan Kerjasama tersebut terlihat pada aspek: (1) saling membantu teman dalam kelompok; (2) ikut menciptakan suasana akrab dalam kelompok; (3) mengakui kelebihan teman dalam kelompok; (4) menerima keputusan yang diambil kelompok; dan (5) berpartisipasi aktif dalam mengerjakan tugas kelompok. Rata-rata tingkat kerjasama siswa meningkat dari $63,95 \%$ pada siklus I menjadi $90,79 \%$ pada siklus II. Dalam hal ini, tujuan penelitian yang ingin dicapai adalah target $75 \%$ semua dapat berhasil dicapai. Artinya, pembelajaran menggunakan media pembelajaran Papeda dapat meningkatkan kerjasama siswa sesuai dengan hipotesis penelitian ini. Peningkatan kerjasama tersebut terjadi karena Papeda dapat memfasilitasi terjadinya interaksi dan sinergitas antar siswa. Siswa terikat satu sama lain melalui pembagian tugas dan tanggungjawab antar siswa.

\subsection{Saran}

Media Pembelajaran Papeda telah terbukti berhasil meningkatkan kerjasama siswa. Guru dapat menggunakan media pembelajaran ini sebagai alternatif media pembelajaran untuk membelajarkan materi penyajian data.

\section{DAFTAR PUSTAKA}

Azhar, A. (2014). Media Pembelajaran. Jakarta: Raja Grafindo Persada.

Endarwati, E. D. (2020). Peningkatan Hasil Belajar Operasi Hitung Bilangan Bulat Melalui Pembelajaran HOTS Berbasis Inquiry Menggunakan Electrical Charges. EDUMAT: Jurnal Edukasi Matematika, 11(2), 88-97.

Lickona, T. (1991). Educating for character how our school can teach respect and responsibility. New York: Bantam Books.

Mahanal, S. (2014). Peran Guru dalam Melahirkan Generasi Emas dengan Keterampilan Abad 21. Seminar Nasional Pendidikan HMPS Pendidikan Biologi FKIP Universitas Halu Oleo, 1(September), 1-16.

Mardati, A. \& Wangid, M. N. (2015). Pengembangan media permainan kartu gambar dengan teknik make a match untuk kelas 1 SD. Jurnal Prima Edukasia 3(2). 120-132. 
McTaggart, R. (1991). Action research: a short modern history. Victoria, Australia: Deakin University Press.

Menteri Pendidikan dan Kebudayaan Republik Indonesia. (2018). Peraturan Menteri Pendidikan dan Kebudayaan Republik Indonesia No 37 Tahun 2018 tentang Kompetensi Inti dan Kompetensi Dasar Pelajaran pada Kurikulum 2013 pada Pendidikan Dasar dan Pendidikan Menengah.

Nur, H. (2013). Membangun Karakter Anak Melalui Permainan Anak Tradisional. Jurnal Pendidikan Karakter, 3(1), 87-94.

Peraturan Menteri Pendidikan dan Kebudayaan Nomor 21 Tahun 2016 tentang Standar Isi Pendidikan Dasar dan Menengah

Retnawati, H., Kartowagiran, B., Hadi, S., \& Hidayati, S. (2011). Identifikasi kesulitan peserta didik dalam belajar matematika dan sains di Sekolah Dasar. Jurnal Kependidikan (2), 162-174.

Rochaniningsih, N. S. \& Masruri, M. S. (2015). Penggunaan metode jigsaw dengan bantuan media untuk meningkatkan keterampilan kerjasama dan hasil belajar IPS. Harmoni Sosial: Jurnal Pendidikan IPS, 2(1), 42-54.

Rusman. (2012). Model-Model Pembelajaran. Depok: PT Raja Grafindo Persada.

Schaefer, M. P. (2012). Determining methods for teaching character education in elementary school (Order No. 3531503). Available from ProQuest Dissetations \& Theses Full Text: The Humanities and Social Sciences Collection. (1151503701).

Sukardi \& Sugiyanti. (2013). Pendidikan Karakter dalam Pembelajaran di Sekolah Dasar Berbasis Kurikulum 2013. Seminar Nasional dan Bedah Buku Pendidikan Karakter dalam Implementasi Kurikulum 2013, 146-158.

Widodo, P. \& Lumintuarso, R. (2018). Pengembangan Model Permainan Tradisional untuk Membangun Karakter pada Siswa SD Kelas Atas. Jurnal Keolahragaan, 5(2), 183. https://doi.org/10.21831/jk.v5i2.7215 